\title{
IMPLEMENTASI SISTEM INFORMASI INVENTARISASI BARANG GUNA PENGENDALIAN INTERNAL
}

\author{
Nofiyani \\ Fakultas Teknologi Informasi, Sistem Informasi, Universitas Budi Luhur, Jakarta, Indonesia \\ Email: nofiyani@budiluhur.ac.id
}

\begin{abstract}
Abstrak-Untuk dapat mencapai tujuan tertentu, perusahaan sering menghadapi permasalahan. Salah satunya adalah barangbarang yang dimiliki perusahaan. Maka dari itu diperlukan pengendalian internal. Jika pengendalian internal atas barang-barang milik perusahaan dapat dilaksanakan dengan baik, maka perusahaan dapat melakukan pengawasan, mengontrol serta meningkatkan efisiensi operasional perusahaan. Dengan melakukan inventarisasi barang yaitu kegiatan pencatatan data yang berhubungan dengan barang-barang atau aset yang di miliki perusahaan, mulai dari pencatatan sampai dengan pemeliharaan. Sistem informasi yang mendukung dapat meningkatkan kinerja perusahaan dalam melakukan pengawasan dan pengontrolan barang-barang yang dimiliki perusahaan. Serta dapat meminimalisir terjadinya kesalahan pencatatan dan menghindari penyimpangan. Diperlukan beberapa tahap pengembangan sistem informasi untuk dapat mengembangkan sistem informasi yang baik. Sehingga dapat terstruktur dan terencana dengan baik sehingga dapat mencapai tujuan yang diharapkan. Diantaranya adalah tahap requirement planning, design system dan implementation. Terdapat 5 entitas yang dapat digunakan dalam kegiatan pencatatan data yang berhubungan dengan barang-barang atau aset yang di miliki perusahaan, sehingga data dapat diolah dan disimpan dengan mudah, diantaranya entitas user, ruang, barang, detil dan inventaris. Terdapat tiga laporan yang dapat digunakan dalam melakukan pengawasan, pengontrolan pengeluaran yang akan dikeluarkan serta meningkatkan efisiensi operasional perusahaan, diantaranya laporan data barang untuk mengetahui rincian barang yang dimiliki perusahaan, laporan data barang per ruangan untuk pengawaan serta kontroling aset perusahaan per ruangan dan laporan inventarisasi dan mutasi barang.
\end{abstract}

Kata Kunci: sistem informasi, inventarisasi, pengendalian internal, control perusahaan, pencatatan data barang

\begin{abstract}
In order to achieve certain goals, companies often face problems. One of them is company-owned goods. Therefore, internal control is needed. If internal control over company property can be implemented properly, the company can supervise, control and improve the company's operational efficiency. By carrying out an inventory of goods, namely the activity of recording data related to goods or assets owned by the company, from recording to maintenance. Supporting information systems can improve company performance in supervising and controlling goods owned by the company. And can minimize the occurrence of recording errors and avoid irregularities. It takes several stages of information system development to be able to develop a good information system. So that it can be well structured and planned so that it can achieve the expected goals. Among them are the requirements planning, system design and implementation stages. There are 5 entities that can be used in data recording activities related to goods or assets owned by the company, so that data can be processed and stored easily, including user entities, space, goods, details and inventory. There are three reports that can be used in monitoring, controlling expenditures to be issued and increasing the company's operational efficiency, including reports on goods data to find out the details of the company's goods, data reports on goods per room for supervision and control of company assets per room and inventory reports and mutation of goods.
\end{abstract}

Keywords: sistem informasi, inventory, internal control, company control, recording of goods data

\section{PENDAHULUAN}

Untuk dapat mencapai tujuan tertentu, perusahaan sering menghadapi permasalahan baik yang berasal dari dalam maupun dari luar perusahaan. Maka dari itu diperlukan pengendalian internal demi kelancaran serta meminimalisir resiko terjadinya kesalahan dan penyimpangan dalam suatu perusahaan [1]. Salah satunya adalah barang-barang yang dimiliki perusahaan. Jika pengendalian internal atas barang-barang milik perusahaan dapat dilaksanakan dengan baik, maka perusahaan dapat melakukan pengawasan, mengontrol pengeluaran yang akan dikeluarkan serta meningkatkan efisiensi operasional perusahaan. Dimana menurut Hery "Pengendalian Internal adalah seperangkat kebijakan dan prosedur untuk melindungi aset atau kekayaan perusahaan dari segala bentuk tindakan penyalahgunaan, menjamin tersedianya informasi akuntansi perusahaan yang akurat, serta memastikan bahwa semua ketentuan (peraturan hukum/undang-undang serta kebijakan manajemen telah dipatuhi atau dijalankan sebagaimana mestinya oleh seluruh karyawan perusahaan [1]. Untuk itu diperlukan pengelolaan data secara rinci dan terstruktur sehingga memudahkan pendataan serta menghindari adanya penyelewengan aset dari oknum yang tidak bertanggung jawab [2].

Inventarisi barang adalah kegiatan pengolahan data menggunakan komputer yang memuat semua barang milik perusahaan yang dipakai untuk melaksanakan kegiatan perusahaan. Inventaris kantor sangatlah penting bagi kelangsungan sebuah perusahaan dan instansi [3]. Inventarisasi mengelola dan mengatur transaksi keluar masuknya 
barang dalam suatu perusahaan. Jika inventarisasi tidak terkontrol maka dapat menyebabkan barang menjadi tidak diketahui keberadaannya dan akan kesulitan dalam melacak keberadaannya [4]. Inventarisasi dilaksanakan setidaknya sekali dalam setahun, berkala dan perlu memperhatikan pengurangan ataupun penambahan barang. Hal tersebut bertujuan supaya perusahaan mempunyai data yang akurat sehingga dapat dipergunakan dalam mempertimbangkan besaran anggaran belanja [5].

Teknologi informasi memberikan pengaruh yang sangat besar dan merambah hampir ke seluruh lapisan masyarakat dan juga bidang usaha [6]. Berdasarkan hal tersebut sistem informasi yang mendukung dalam melakukan pengolahan data menggunakan teknologi informasi akan meningkatkan kinerja perusahaan dalam melakukan pengawasan, pengontrolan barang-barang yang dimiliki perusahaan. Dengan adanya sistem informasi data dapat diolah dan disimpan dengan mudah sehingga dapat menghasilkan informasi yang tepat dan akurat serta dapat meminimalisir terjadinya kesalahan pencatatan dan menghindari penyimpangan oleh oknum yang tidak bertanggung jawab [7]. Dengan menggunakan sistem informasi inventarisasi barang dapat membantu meringankan dan memepercepat proses pencatatan transaksi inventarisasi [8].

Pada penelitian yang dilakukan oleh [3] merancang sistem informasi inventaris barang di dinas dengan menggunakan pemodelan DFD (Data Flow Diagram). Sedangkan bahasa pemrograman yang digunakan dalam penelitiannya adalah visual basic studio 2012 dan database MySQL Server 2012.

Penelitian yang dilakukan [4] membangun sistem informasi inventarisasi barang di IM2 Indosatnet Bandung menggunakan bahasa pemrograman Borland Delphi 7 dan database MySql. Bahasa pemrograman borland delphi dan visual basic yang digunakan pada penelitian diatas hanya terbatas pada OS (Windows). Untuk itu dalam penelitian ini penulis menggunakan bahasa pemrograman java yang bersifat portable sehingga dapat digunakan dalam segala OS sehingga user tak terkendala dengan OS tertentu.

Pada penelitian yang dilakukan oleh [7] dengan mengembangkan sistem informasi inventaris barang berbasis web. Begitu juga penelitian yang dilakukan oleh [8]. Bahasa pemrograman berbasis web membutuhkan koneksi internet untuk menjalankannya. Untuk itu dalam penelitian ini penulis menggunakan bahasa pemrograman berbasis dekstop sehingga dapat berjalan dengan independen, tanpa perlu browser dan koneksi internet.

\section{METODE PENELITIAN}

\subsection{Metode Penelitian}

Metode penelitian yang digunakan dalam penelitian ini adalah metode penelitian kualitatif, dimana data diperoleh dengan melakukan:

a. Wawancara untuk memperoleh data yang lebih lengkap.

b. Observasi untuk mengamati secara langsung prosedur sistem berjalan.

c. Analisa dokumentasi yang tersedia atau yang sudah dikumpulkan.

\subsection{Metode Pengembangan Sistem}

Rapid Application Development (RAD) adalah metode pengembangan sistem yang digunakan dalam penelitian ini, yang merupakan model pengembangan perangkat lunak yang termasuk dalam teknik inkremental (bertingkat). RAD menekankan pada pengembangan perangkat lunak yang pendek, singkat, dan cepat [9]. Model RAD mempunyai tiga tahapan seperti terlihat pada Gambar 1:

a. Requirement Planning dimana pada tahapan ini pengguna dan analis akan bertemu untuk mengidentifikasi permasalahan dan yang menjadi tujuan dibangunnya sistem dan juga mengidentifikasi informasi yang dibutuhkan untuk mencapai tujuan tersebut. Orientasinya adalah menyelesaikan masalah-masalah pengguna sistem.

b. Design System merupakan tahap merancang dan melakukan perbaikan. Analis dan programmer bekerja sama dalam membangun representasi visual desain dan pola kerja sistem kepada pengguna. Kemudian analis akan memperbaiki rancangan berdasarkan masukan dan respon dari pengguna. Pola kerja ini akan mendorong pengembangan hingga tingkat akhir. Keaktifan pengguna yang terlibat menentukan pencapaian tujuan karena akan dilakukan proses desain dan perbaikan-perbaikan apabila masih terdapat ketidaksesuaian desain antara pengguna dan analis.

c. Implementation adalah tahap programmer akan mengembangkan desain sistem yang telah disetujui oleh penguna dan analis. Sebelum diaplikasikan pada suatu perusahaan, harus dilakukan ujicoba terlebih dahulu untuk mengetahui apakah masih terdapat kesalahan atau tidak. 


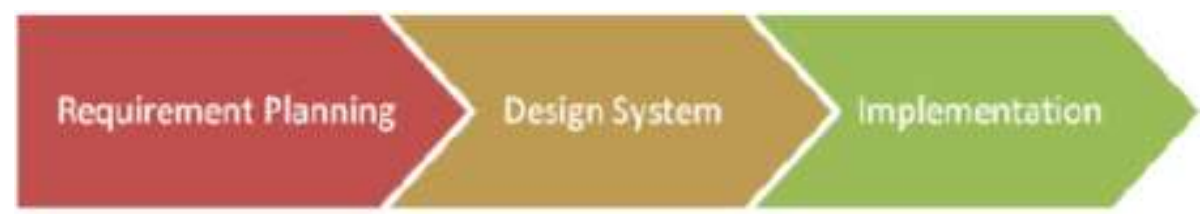

Gambar 1. Tahapan Pengembangan Sistem Metode Rapid Application Development (RAD) [9]

\section{HASIL DAN PEMBAHASAN}

\subsection{Requirement Planning (Tahapan Rencana Kebutuhan)}

a. Uraian Prosedur atau Prosedur Kerja Sistem Usulan:

1) Pendataan Barang

Petugas akan melakukan pendataan setiap ada barang baru yang datang atau dibeli. Dengan mencatat data barang dalam form barang. Setelah dilakukan pendataan, petugas akan menempelkan kode barang pada barang tersebut.

2) Pencatatan Inventarisasi dan Mutasi Barang

Petugas akan melakukan proses transaksi inventarisasi dan mutasi barang dengan mencatat data dalam form inventarisasi dan mutasi barang. Setelah itu barang dapat diserahkan/dikirimkan ke unit/ruangan yang membutuhkan.

3) Pembuatan Laporan

Laporan akan dibuat setiap akhir bulan untuk pertanggung jawaban ke pimpinan, laporan data barang untuk mengetahui rincian barang yang dimiliki perusahaan, laporan data barang per ruangan untuk pengawaan serta kontroling aset perusahaan per ruangan dan laporan inventarisasi dan mutasi barang untuk mengetahui rincian permintaan dan kebutuhan barang,

b. Kebutuhan Informasi

Terdapat tiga informasi yang dibutuhkan guna melakukan pengawasan serta kontroling aset yang dimiliki perusahaan diantaranya dapat dilihat pada Tabel 1 dibawah ini:

Tabel 1. Kebutuhan Informasi Pada Sistem Usulan

\begin{tabular}{|l|l|l|l|}
\hline \multicolumn{1}{|c|}{ No. } & \multicolumn{1}{|c|}{ Informasi } & Tujuan & \multicolumn{1}{c|}{ Frekuensi } \\
\hline Laporan Data Barang & $\begin{array}{l}\text { Untuk mengetahui rincian barang } \\
\text { yang dimiliki perusahaan }\end{array}$ & Pimpinan & Setiap akhir bulan \\
\hline $\begin{array}{l}\text { Laporan Data Barang Per } \\
\text { Ruangan }\end{array}$ & $\begin{array}{l}\text { Untuk pengawaan serta kontroling } \\
\text { aset perusahaan per ruangan }\end{array}$ & Pimpinan & Setiap akhir bulan \\
\hline $\begin{array}{l}\text { Laporan Inventarisasi Dan Mutasi } \\
\text { Barang }\end{array}$ & $\begin{array}{l}\text { Untuk mengetahui rincian } \\
\text { permintaan dan kebutuhan barang }\end{array}$ & Pimpinan & Setiap akhir bulan \\
\hline
\end{tabular}

c. Use Case Diagram

1) File Master

File/tabel master merupakan tabel yang terdiri di kolom-kolom yang memiliki ketergantungan total pada satu primary key [10]. Terdapat tiga file master yang terbentuk terlihat pada Gambar 2.

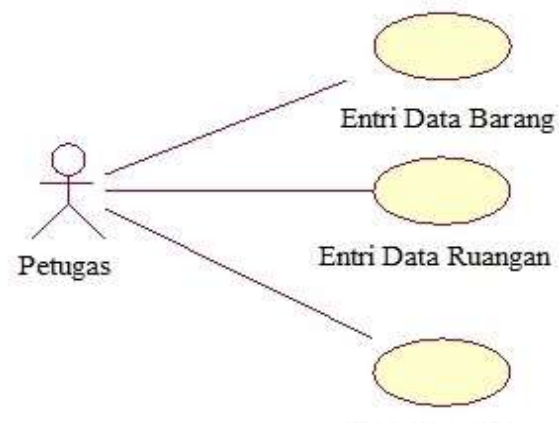

Entri Data User

Gambar 2. Rancangan Use Case Diagram File Master 
Available online at http://jom.fti.budiluhur.ac.id/index.php/IDEALIS/index

2) Inventarisasi dan Mutasi

Pencatatan data transaksi inventarisasi dan mutasi barang akan dilakukan oleh petugas dalam form inventarisasi dan mutasi barang seperti digambarkan pada Gambar 3.

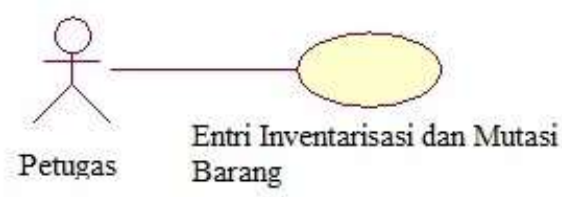

Gambar 3. Rancangan Use Case Diagram Inventarisasi dan Mutasi Barang

3) Laporan

Laporan akan dibuat oleh petugas dan akan diserahkan kepada pimpinan seperti digambarkan pada use case diagram Gambar 4.

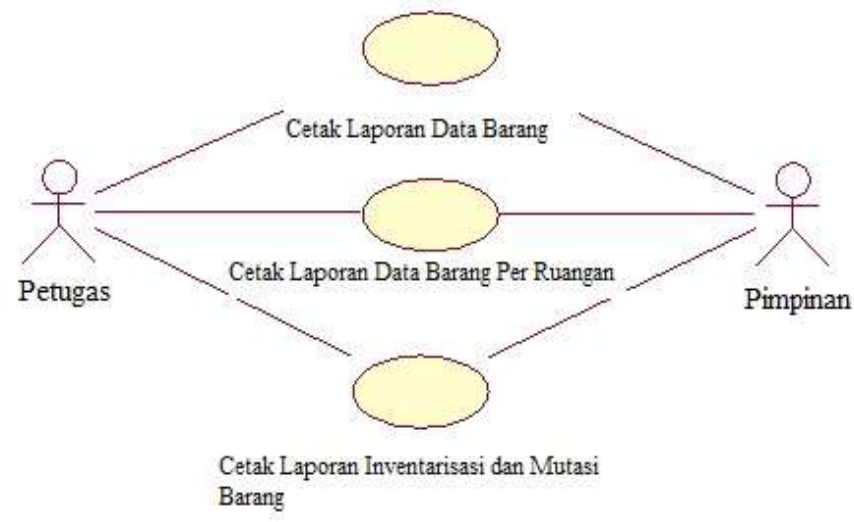

Gambar 4. Rancangan Use Case Diagram Laporan

\subsection{Design System (Tahapan Desain Sistem)}

a. Logical Database Design

Pemilihan DBMS yang akan digunakan untuk implementasi rancangan database dan mengubah konsep rancangan database menjadi skema database kedalam model data DBMS yang dipilih. Rancangan class diagram yang menggambarkan struktur sistem yang akan digunakan dalam pengembangan sistem usulan dapat dilihat pada Gambar 5.

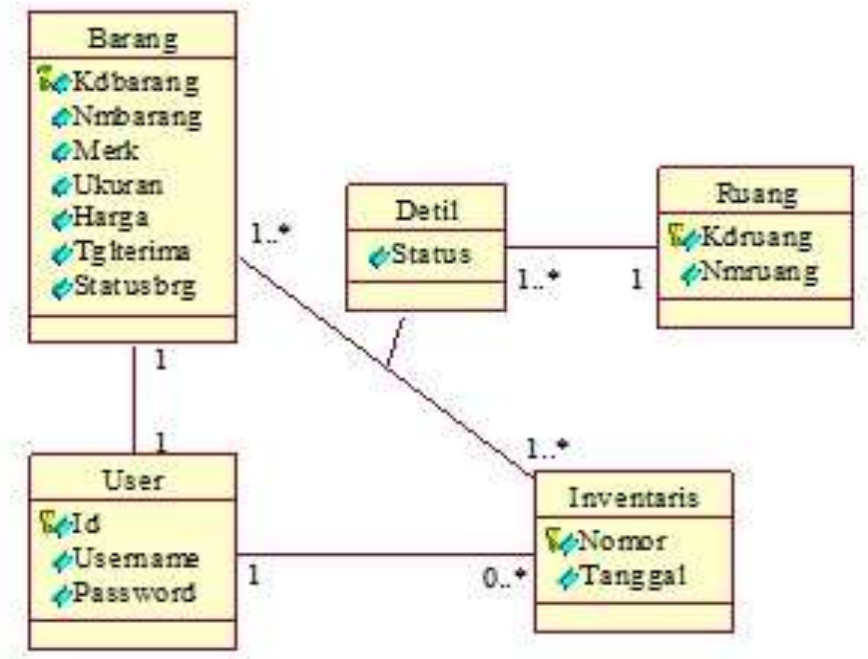

Gambar 5. Rancangan Class Diagram Sistem Usulan 


\section{ISSN 2684-7280 (online)}

Halaman 55-62

Available online at http://jom.fti.budiluhur.ac.id/index.php/IDEALIS/index

b. Desain Interface

1) Struktur Tampilan Menu

Perancangan tampilan sistem merupakan sebuah sketsa penggambaran keadaan dari sistem yang dibangun. Perancangan struktur menu dapat dilihat pada Gambar 6.

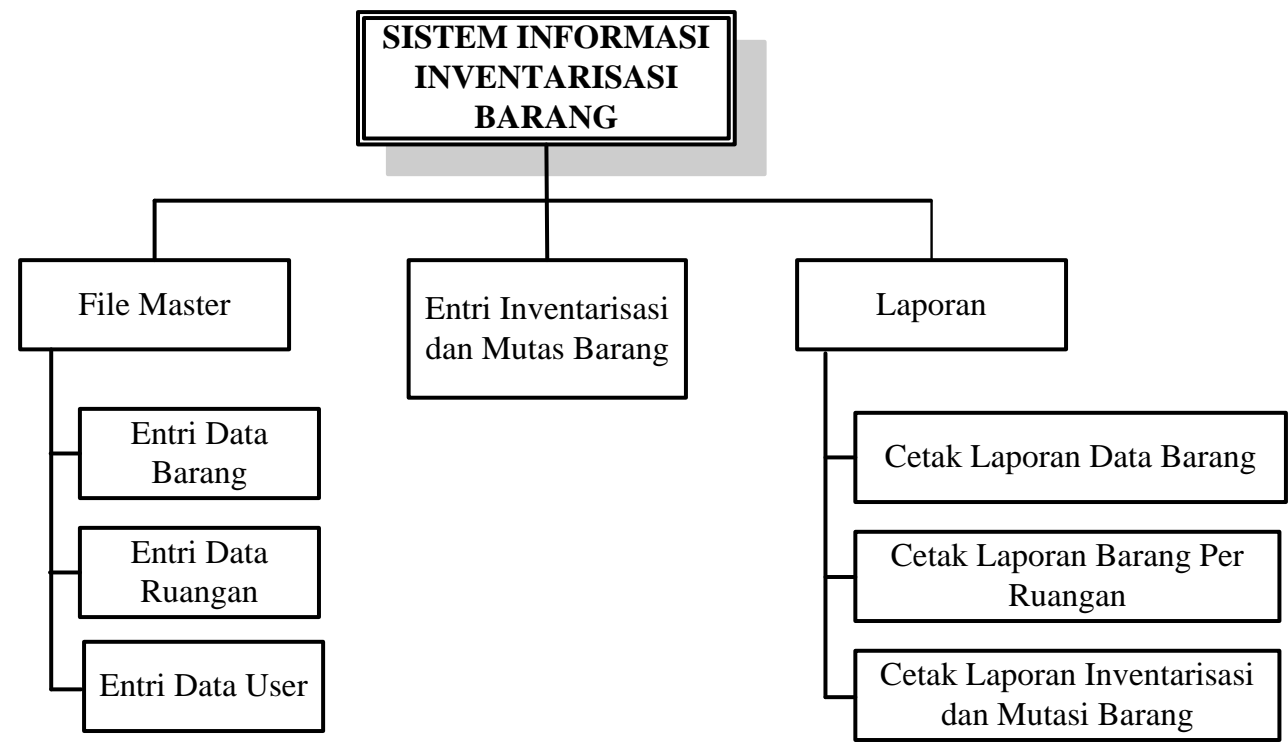

Gambar 6. Struktur Tampilan Menu Sistem Usulan

2) Tampilan Entri Data Barang

Rancangan tampilan form entry data barang yang akan digunakan untuk mencatat setiap ada barang baru yang datang atau dibeli. Lihat Gambar 7.

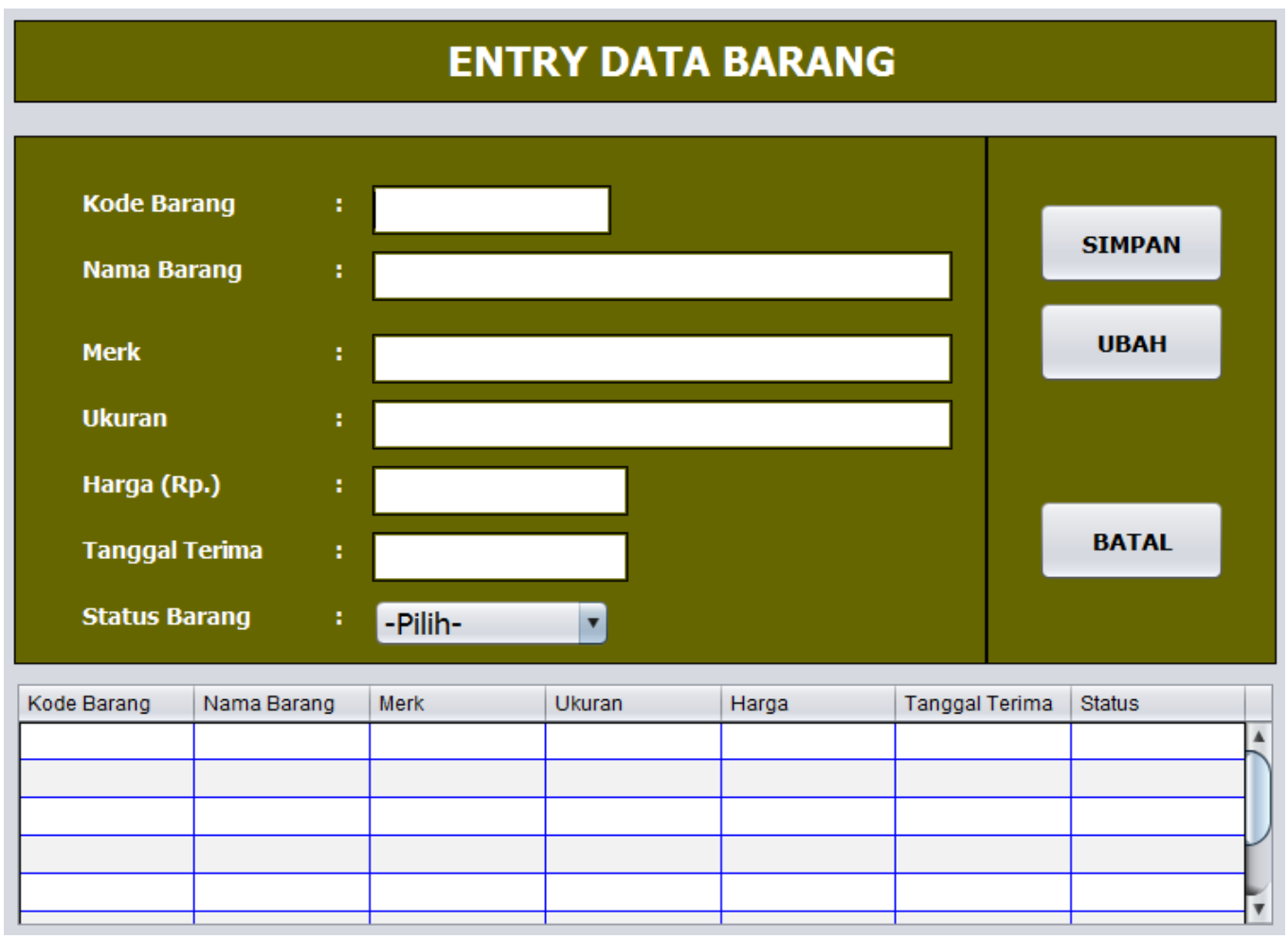

Gambar 7. Tampilan Form Entry Barang 


\section{ISSN 2684-7280 (online)}

Halaman 55-62

Available online at http://jom.fti.budiluhur.ac.id/index.php/IDEALIS/index

3) Tampilan Entri Inventarisasi dan Mutasi Barang

Proses transaksi inventarisasi dan mutasi barang dientri dan simpan dalam form inventarisasi dan mutasi barang sebelum diserahkan/dikirimkan ke unit/ruangan yang membutuhkan. Lihat Gambar 8 .

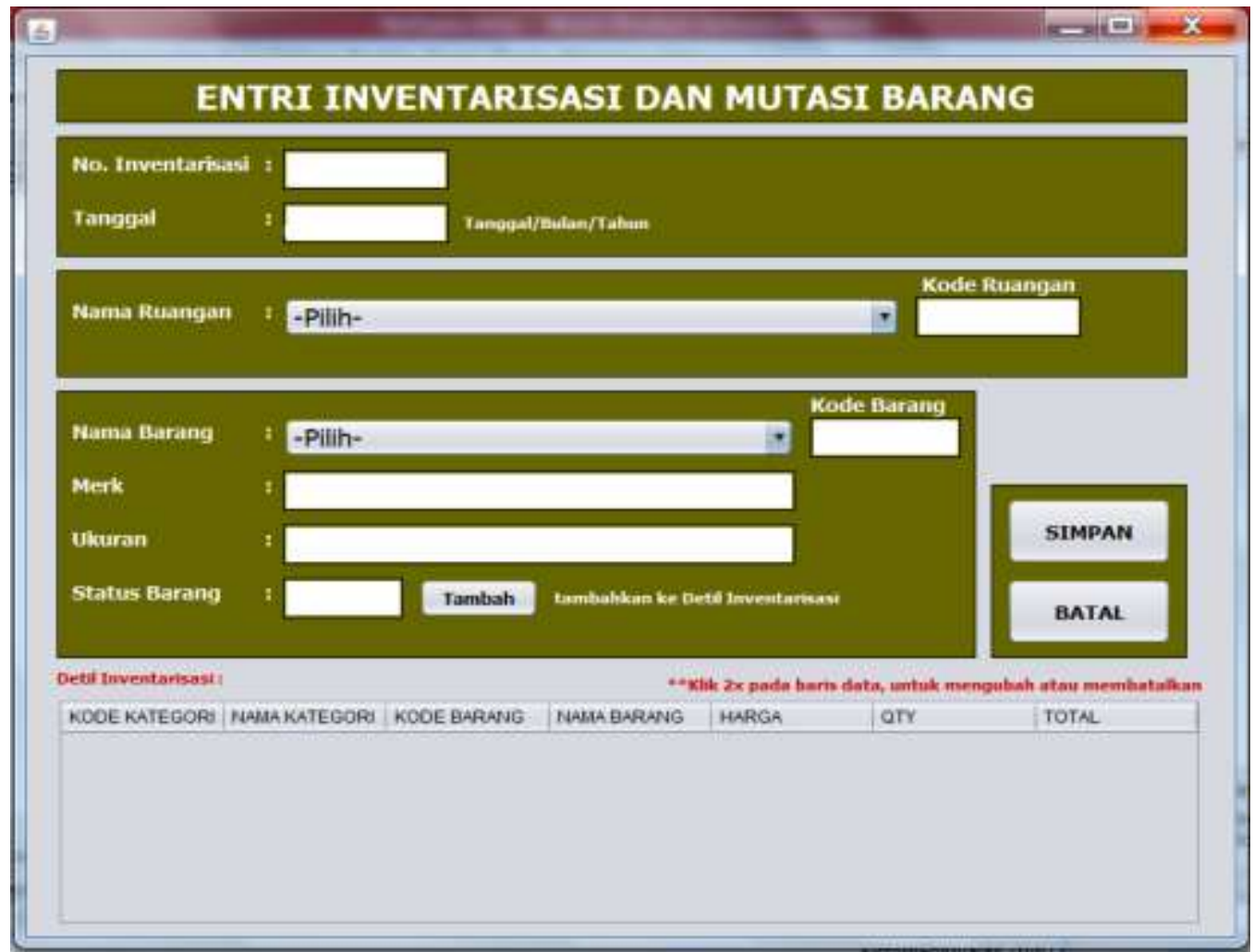

Gambar 8. Tampilan Form Entry Inventarisasi dan Mutasi Barang

4) Tampilan Laporan Data Barang

Rancangan laporan data barang yang akan dibuat setiap akhir bulan sebagai pertanggung jawaban petugas ke pimpinan terlihat pada Gambar 9.

\section{LAPORAN DATA BARANG}

\begin{tabular}{|c|c|c|c|c|c|c|c|}
\hline No. & $\begin{array}{c}\text { Kode } \\
\text { Barang }\end{array}$ & Nama Barang & Merk & Ukuran & Harga & Tanggal Terima & Status Barang \\
\hline$\frac{99}{7}$ & $\stackrel{\mathrm{x}-6-\mathrm{x}}{7}$ & $\stackrel{\mathrm{x}-30-\mathrm{x}}{7}$ & $\stackrel{\mathrm{x}-30-\mathrm{x}}{7}$ & $\stackrel{\mathrm{x}-30-\mathrm{x}}{7}$ & $\frac{999,999,999}{7}$ & $\stackrel{\mathrm{dd} / \mathrm{mm} / \mathrm{yyy}}{ }$ & $\stackrel{\mathrm{x}-10-\mathrm{x}}{7}$ \\
\hline
\end{tabular}

Tgl. Cetak:

Gambar 9. Tampilan Rancangan Laporan Data Barang

5) Tampilan Laporan Data Barang Per Ruangan

Rancangan laporan data barang per ruangan yang akan digunakan dalam pengawaan serta kontroling aset perusahaan per ruangan dapat dilihat pada Gambar10. 


\section{LAPORAN INVENTARISASI BARANG PER RUANGAN}

Nama Ruangan :
\begin{tabular}{|c|c|c|c|c|}
\hline No. & Kode Barang & Nama Barang & Merk & Ukuran \\
\hline 99 & $\mathrm{x}-6-\mathrm{x}$ & $\mathrm{x}-30-\mathrm{x}$ & $\mathrm{x}-30-\mathrm{x}$ & \\
\hline 7 & & & & \\
\hline
\end{tabular}

Tgl. Cetak:

Gambar 10. Tampilan Rancangan Laporan Data Barang per Ruangan

6) Tampilan Laporan Inventarisasi dan Mutasi Barang

Rancangan laporan inventarisasi dan mutasi barang untuk mengetahui rincian permintaan dan kebutuhan barang dalam periode tertentu dapat dilihat pada Gambar 11.

\section{LAPORAN INVENTARISASI DAN MUTASI BARANG}

Periode : dd $/ \mathrm{mm} /$ yyy s $/ \mathrm{d} d \mathrm{dd} / \mathrm{mm} / \mathrm{yyyy}$

\begin{tabular}{|c|c|c|c|c|c|c|c|}
\hline No. & $\begin{array}{c}\text { Nomor - Tanggal } \\
\text { Transaksi Mutasi }\end{array}$ & Kode Barang & $\begin{array}{c}\text { Nama } \\
\text { Barang }\end{array}$ & Merk & Ukuran & Nama Ruangan & Status Inventarisasi \\
\hline 99 & $\mathrm{x}-20-\mathrm{x}$ & $\mathrm{x}-6-\mathrm{x}$ & $\mathrm{x}-30-\mathrm{x}$ & $\mathrm{x}-30-\mathrm{x}$ & $\mathrm{x}-30-\mathrm{x}$ & $\mathrm{x}-30-\mathrm{x}$ & $\mathrm{x}-5-\mathrm{x}$ \\
7 & & & & & & \\
\hline
\end{tabular}

Tgl. Cetak:

Gambar 11. Tampilan Rancangan Laporan Inventarisasi dan Mutasi Barang

\subsection{Implementation (Tahapan Implementasi)}

Tahapan Perencanaan:

a. Mempersiapan data dan software yang akan digunakan

b. Instalasi software yang sudah disiapkan

c. Menentuan user yang akan mempunyai hak akses ke sistem

d. Melakukan pelatihan kepada user

e. Melakukan sosialisasi kepada semua pihak-pihak yang terkait

f. Melakukan uji coba sistem untuk mengetahui apakah sistem sudah berjalan dengan baik atau apakah masih harus dilakukan perbaikan

g. Dilakukan evaluasi dan perbaikan setelah melakukan uji coba sistem

h. Membuat dokementasi sistem yang dibutuhkan oleh sistem analis, pemakai sistem, dan auditor.

i. Melakukan pengujian sistem untuk mendeteksi adanya ketidakkonsistenan sistem

\section{KESIMPULAN}

Kesimpulan yang dapat diambil dari penelitian ini yaitu diperlukan beberapa tahap pengembangan untuk dapat mengembangkan sistem informasi yang baik. Sehingga dapat terstruktur dan terencana dengan baik sehingga dapat mencapai tujuan yang diharapkan. Diantaranya adalah tahap requirement planning, design system dan implementation. Terdapat 5 entitas yang dapat digunakan dalam kegiatan pencatatan data yang berhubungan dengan barang-barang atau aset yang di miliki perusahaan, sehingga data dapat diolah dan disimpan dengan mudah, diantaranya entitas user, ruang, barang, detil dan inventaris. Terdapat tiga laporan yang dapat digunakan dalam melakukan pengawasan, pengontrolan pengeluaran yang akan dikeluarkan serta meningkatkan efisiensi operasional perusahaan, diantaranya laporan data barang untuk mengetahui rincian barang yang dimiliki perusahaan, laporan data barang per ruangan untuk pengawaan serta kontroling aset perusahaan per ruangan dan laporan inventarisasi dan mutasi barang. 


\section{DAFTAR PUSTAKA}

[1] R. Pasaribu, "Analisis Penerapan Pengendalian Internal Atas Aset Tetap Pada PT. Perkebunan Nusantara IV (Persero), In Skripsi, Fakultas Ekonomi dan Bisnis Universitas Medan Area Medan,” 2019.

[2] Khairullah, B. Soedijono, And H. Al Fatta, "Pengukuran Kualitas Sistem Informasi Inventaris Aset Universitas Muhammadiyah Bengkulu Menggunakan Metode Mccall,” Jurnal Informasi Interaktif, vol. 2, vo. 2, pp. 84-92, 2017.

[3] I. Setia Andani And L. F. Diana, "Analisa Dan Perancangan Sistem Informasi Inventaris Barang Pada Dinas Kependudukan Dan Pencatatan Sipil Kabupaten Kudus,” Prosiding Snatif Ke-3, 2016, pp. 269-27.

[4] I. A. Dewi, "Desain Dan Implementasi Sistem Inventarisasi IM2 Indosatnet Bandung Berbasis Desktop," Jurnal Informatika, vol. 5, no. 2, pp.1-10, 2015.

[5] "Pengertian Inventarisasi," [Online]. Available:https://jagad.id/pengertian-inventarisasi/, 2020.

[6] L. Eunike Sihotang And A. Umar Hamdani, "Implementasi Sistem Penjualan Berbasis E-Commerce Untuk Meningkatkan Pendapatan Pada Toko Xyz Collection,” IDEALIS, vol. 3, no. 2, Pp. 1-8, 2020.

[7] A. Syukri And A. Ambarita, "Information System of Inventory Goods Web-Based On The," IDEALIS, vol. 1, no. 1, pp. 31-38, 2016.

[8] A. Maulana, M. Sadikin, And A. Izzuddin, "Implementasi Sistem Informasi Manajemen Inventaris Berbasis Web Di Pusat Teknologi Informasi Dan Komunikasi - Bppt,”, SETRUM, vol. 7, no. 1, pp. 182-196, 2018.

[9] Nofiyani, "Meningkatkan Pelayanan Dan Akuntabilitas Melalui Pengembangan Sistem Informasi Pada Administrasi Service Kendaraan Bermotor," Jurti (Jurnal Teknologi Informasi), vol. 4, no. 1, pp. 152-159, 2020.

[10] D. Puspitasari, C. Rahmad, And M. Astiningrum, "Normalisasi Tabel Pada Basisdata Relasional," In Prosiding Sentia, 2016, Politeknik Negeri Malang, vol. 8, no.1, pp. 340-345. 